\title{
Distinct nonrandom patterns of chromosomal deletions in giant-cell lesions of bone
}

\author{
Marcelo Razera Baruffi ${ }^{1}$, J. Barbieri-Neto ${ }^{2}$, João Monteiro Pina-Neto ${ }^{1}$, C.E. Suerzut ${ }^{3}$ and Cacilda Casartelli ${ }^{1}$ \\ ${ }^{1}$ Department of Genetics, School of Medicine of Ribeirão Preto, University of São Paulo, \\ Ribeirão Preto, SP, Brazil. \\ ${ }^{2}$ Department of Pathology, School of Medicine of Ribeirão Preto, University of São Paulo, \\ Ribeirão Preto, SP, Brazil. \\ ${ }^{3}$ Departament of Surgery and Traumatology, School of Odontology of Ribeirão Preto, \\ University of São Paulo, Ribeirão Preto, SP, Brazil.
}

\begin{abstract}
Cytogenetic analyses were performed on a bone giant cell reparative granuloma (GCRG) and on three bone giant cell tumors (GCT). The present GCRG case is the second to be described cytogenetically. A modal chromosome number of 46 was observed in all samples. Clonal chromosome abnormalities were detected in all cases. The numerical alterations most frequently observed involved the loss of chromosomes 17 and 18. Among the structural anomalies observed, there was preferential involvement of chromosomes 6 and 10. Three GCT cases presented del(10)(p13) and two cases presented del(6)(q25) (1 GCRG and 1 GCT). These breakpoints mapped on 10p and $6 q$ may harbour genes of importance in the development of bone giant cell tumors.
\end{abstract}

Key words: bone, giant-cell, granuloma, tumor, chromosome.

Received: March 12, 2002; accepted: August 13, 2002.

\section{Introduction}

Giant-cell tumors (GCT) and giant-cell lesions form a group of clinicopathologic entities that differ in their behavior and may present substantial problems in differential diagnosis. Some are true neoplasms, whereas others represent a heterogeneous group of reparative or reactive reactions. The ubiquitous presence of multinucleated giant cells in many unrelated lesions complicates their classification (Dorfman and Czerniak, 1998). Conventional GCT are aggressive lesions, have local recurrence and low metastatic potential. They are characterized by well-vascularized tissue made up of plump, spindly, or ovoid cells in addition to numerous multinucleated giant cells uniformly dispersed throughout the tumor tissue (Schajowicz, 2000). This lesion represents $5 \%$ of the primary bone tumors. More than $80 \%$ of the GCT occur in patients older than 20 years of age, i.e., in skeletally mature individuals. More than $75 \%$ of the GCT are situated at or near the articular end of a long tubular bone. The distal femur, proximal tibia and fibula are affected in half of the cases (Huvos, 1991).

Send correspondence to Cacilda Casartelli. Depto. de Genética, Faculdade de Medicina de Ribeirão Preto, Universidade de São Paulo, Av. Bandeirantes 3900, 14049-900 Ribeirão Preto, SP, Brazil. E-mail: ccasarte@fmrp.usp.br.
Bone giant-cell reparative granuloma (GCRG) is a rare non-neoplastic lesion. Histologically, stromal cells between larger or smaller clusters of giant cells display storiform, matted or herringbone growth patterns (Huvos, 1991). The fibrous stroma is prominent, with fusiform cells, areas of hemorrhage and giant cell clusters or nests smaller than a true giant cell tumor (Schajowicz, 2000). The incidence of this lesion is higher at the beginning of the second decade of life. Craniofacial bones, the mandible and maxilla are usually affected, whereas the lesion is extremely rare in long tubular bones and vertebrae (Dorfman and Czerniak, 1998).

Only one case of GCRG has been described cytogenetically. The karyotype was: 46,XY,t(X;4)(q22;q31.3) [3]/46XY[10] (Buresh et al. 1999). GCT present chromosome alterations with multiple telomere associations involving 4p, 8p, 11p, 14p, 17p, 14q, 19q and 20q (Schwartz et al. 1991; Bridge et al. 1993) and translocations involving chromosomes 1, 2, 11p, 12,18p, 13p, 15p, and 19 (Noguera et al. 1989; Bridge 1990; Dal Cin et al. 1994). Monosomies and trisomies involve mainly chromosomes 19, 11, 20, 18 and 22 in decreasing order of frequency (Mitelman et al. 1998). 
In this paper we describe the chromosome alterations detected in cells of a GCRG and three GCT. Deletion del(10)(p13), not reported before, was present at high frequency in the three GCT described here.

\section{Subject and Methods}

\section{Case reports}

Case 1-A 13-year-old boy presented various axillary ephelides and lenticular, nummular and plaque-like café-au-lait spots covering the entire trunk, abdomen and limbs. At seven years of age the patient had shown three cutaneous neurofibromas and bulging in the malar region with poor tooth implantation. He was taken to an orthodontic service where a slightly insufflating osteolytic lesion partially involving the maxilla and mandible was detected by computed tomography. After surgery for resection of the tumor mass, the anatomopathologic report showed a benign intraosseous lesion consisting of fibrous tissue and giant cells characterizing a giant cell reparative granuloma (Figure $1 \mathrm{~A})$.

Case 2 - A 33-year-old man reporting natural pain (without palpation) of six months duration and an increased volume of the left knee with limping gait on the right was submitted to computed tomography, which revealed an expansive condylo-epiphyseal lesion in the right femur. After surgery and histopathological analysis, a diagnosis of a giant cell bone tumor was confirmed.

Case 3 - A 26-year-old man had been experiencing natural pain (without palpation) in the right knee for 8 months; after three months abnormal growth was detected in the right tibia. Histopathological analysis confirmed the diagnosis of a giant cell bone tumor.

Case 4 - A 19-year-old man with an initial clinical diagnosis of cauda equina syndrome was submitted to radiological examinations which revealed an expansive bone lesion in the sacral region. Histopathological analysis confirmed the diagnosis of a giant cell bone tumor (Figure 1B).

\section{Cytogenetic analysis}

Fresh tumor tissue samples were analyzed cytogenetically after medium-term in vitro culture (7 to 10 days). The material was sent by the University Hospital of the School of Medicine at Ribeirão Preto, São Paulo, Brazil. Fresh tissue samples collected under sterile conditions were processed promptly. Chromosome preparation was performed according to a previously described protocol (Baruffi et al. 2001). Chromosome studies were carried out on primary cultures only. Slides were subjected to GTG banding (Scheres, 1972). The International Standard for Human Cytogenetic Nomenclature (ISCN 1995) was used for karyotypic description. A further requirement for clonality was that the chromosome alterations had to be found in at least in two different culture flasks.

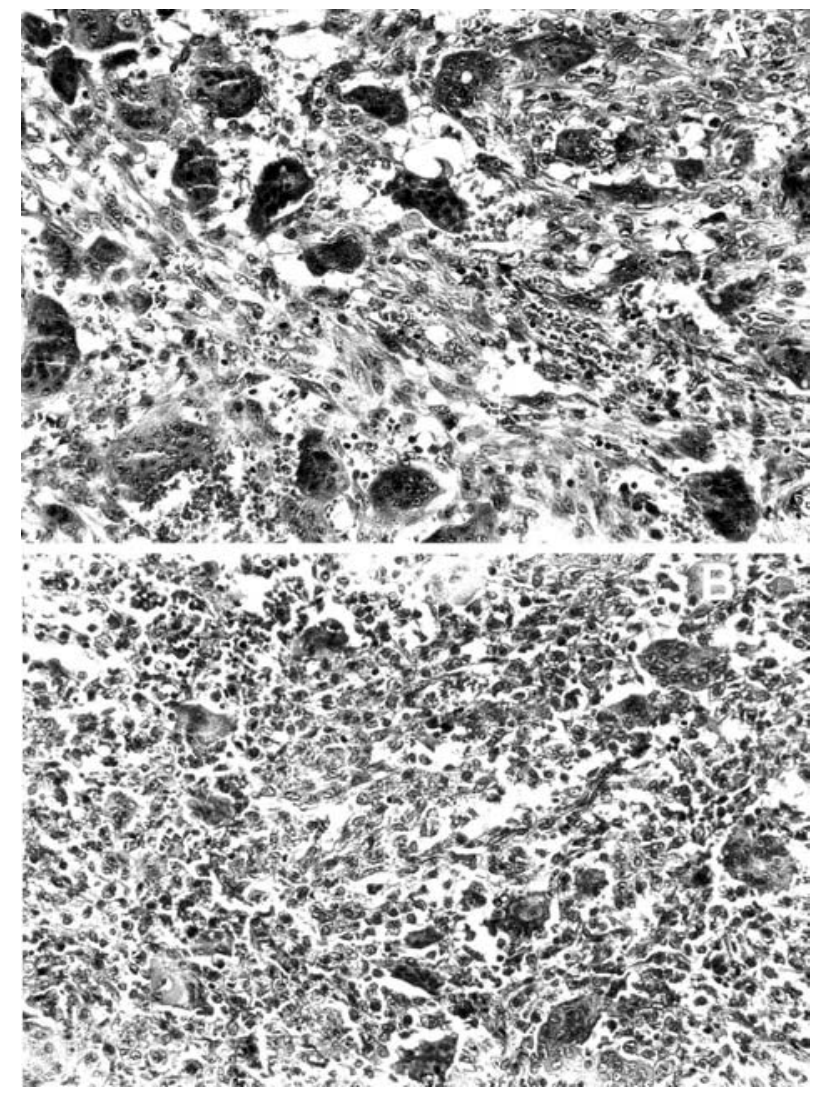

Figure 1 - (A) Photomicrograph showing the proliferation of fusiform cells with elongated nuclei and tapering ends, intermingled with multinucleated giant cells with rounded nuclei and a small number of lymphoid cells (case 1). (B) Photomicrograph showing the proliferation of elongated cells with a rounded nucleus diffusely intermingled with multinucleated giant cells. The shape of the nucleus of these cells is similar to that of the cells described earlier (case 4).

\section{Results}

Cellular morphology showed growth of mesenchymal cells in early primary cultures. Metaphases were obtained from dividing cells in the early growth cycle to prevent the overgrowth of fibroblasts observed in older cultures. On average, 10-15 day old cell cultures with high mitotic activity were prepared for cytogenetic investigation. Chromosome counts were performed after standard staining in a total of 100 cells per case. The modal chromosome number was 46 . Hypodiploidy varying from 43 to 45 chromosomes was detected at higher frequency in the GCT: $15 \%$ (case 1), $42 \%$ (case 2), $31 \%$ (case 3 ) and 26\% (case 4 ). Table 1 summarizes the clinical, pathologic and cytogenetic data.

The most frequent chromosome alterations detected in the GCRG were monosomies of chromosomes 14, 17, 18 and 22 and the deletions $\operatorname{del}(6)(\mathrm{q} 25), \operatorname{del}(7)(\mathrm{q} 33)$ and $\operatorname{del}(18)(\mathrm{p} 11.2)$ (Figure 2). The GCT had in common the deletion del(10)(p13) in common (Figure 3). 
Table I - Clinical and histopathological data and cytogenetic results of the bone giant cell tumors analyzed.

\begin{tabular}{|c|c|c|c|}
\hline Case & Age (years)/ Sex & Histopathologic diagnosis/location & Composite karyotype \\
\hline 1 & $12 / \mathrm{M}$ & $\begin{array}{l}\text { Bone giant cell reparative } \\
\text { granuloma/mandible }\end{array}$ & $\begin{array}{l}40 \sim 49, \mathrm{XY},-5[4], \operatorname{del}(6)(\mathrm{q} 25)[3], \operatorname{del}(7)(\mathrm{q} 33)[4],-11[4],+11[3], \\
-14[6],-17[6], \operatorname{del}(18)(\mathrm{p} 11.2)[4],-18[6],-22[6][\mathrm{cp} 25] / 46, \mathrm{XY}[11]\end{array}$ \\
\hline 2 & $33 / \mathrm{M}$ & Bone giant cell tumor/right femur & $41 \sim 46, \mathrm{XY}, \operatorname{del}(10)(\mathrm{p} 13)[3],-17[3][\mathrm{cp} 9] / 46 \mathrm{XY}[1]$ \\
\hline 3 & $26 / \mathrm{M}$ & Bone giant cell tumor/right tibia & $\begin{array}{l}39 \sim 48, X Y,-6[6], \operatorname{del}(10)(\mathrm{p} 13)[7],-10[5],+17[2],-18[3][\mathrm{cp} 18] / 46 \\
\mathrm{XY}[1]\end{array}$ \\
\hline 4 & 19/M & Bone giant cell tumor/sacral region & $\begin{array}{l}40 \sim 47, \mathrm{XY}, \operatorname{del}(6)(\mathrm{q} 25)[3],-7[5], \operatorname{del}(10)(\mathrm{p} 13)[5],-19[6],-20[3] \\
+\operatorname{mar}[3][\operatorname{cp} 22] / 46, X Y[6]\end{array}$ \\
\hline
\end{tabular}

A

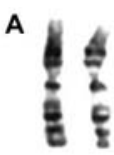

1

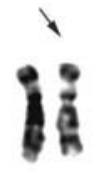

6
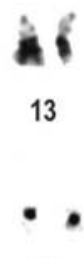

19

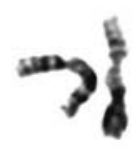

2

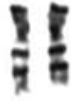

7

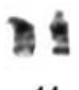

14

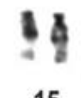

15

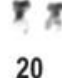

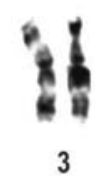
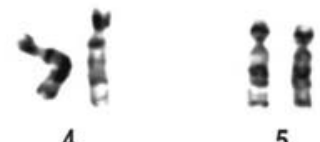

5
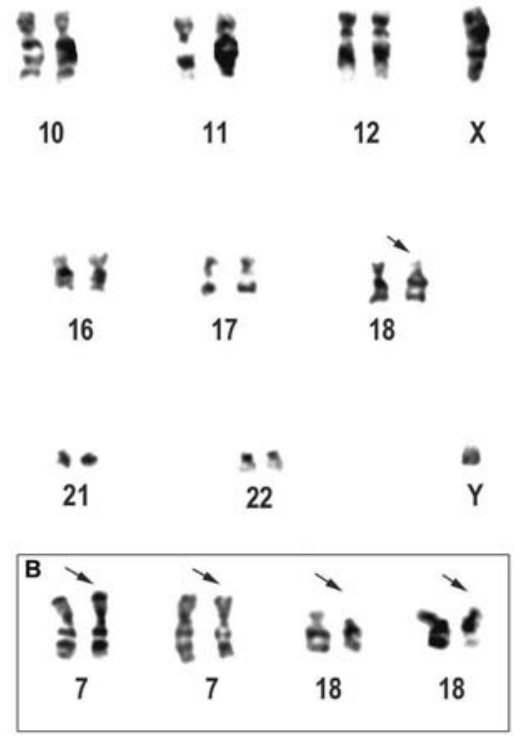

Figure 2 - (A) Representative G-banded karyotype of case 1: 46,XY,del(6)(q25),del(18)(p11). (B) Partial karyotype showing del(7)(q33) and $\operatorname{del}(18)(\mathrm{p} 11)$.

\section{Discussion}

Lesions such as aneurysmal bone cysts and giant cell tumors may simulate reparative giant cell granulomas both clinically and radiologically. Chromosomal analyses of three cases of aneurysmal bone cysts have been recently reported recently (Panoutsakapoulos et al. 1999). Two presented $\mathrm{t}(16 ; 17)(\mathrm{q} 22 ; \mathrm{p} 13)$ as the only abnormality, and the third case showed del(16)(q22) (Panoutsakapoulos et al. 1999). The only case of GCRG in the literature, which was cytogenetically analyzed, did not have alterations involving chromosome 16 (Buresh et al. 1999).

In the present paper we report an additional case of GCRG whose results showed a complex karyotype with monosomy of chromosomes $14,17,18$, and 22 as the most frequent aneuploidies. The other alterations $(-5,-11,+11)$ were present at low frequencies. Numerous chromosome alterations, mainly numerical, are typical of non-neoplastic proliferative processes of the bone (Baruffi et al. 2001). Apparently, most of them are not associated with tissue transformation to a neoplastic stage, and are probably due to the high cell division rate. The increased cell proliferation rate generates genetic instability, promoting random chromosomal alterations and increasing the possibility of the formation of abnormal clones (Bale et al. 1986). In addition, all cases showed normal cells although at low frequency. In tissue culture, neoplastic cells from benign 
A
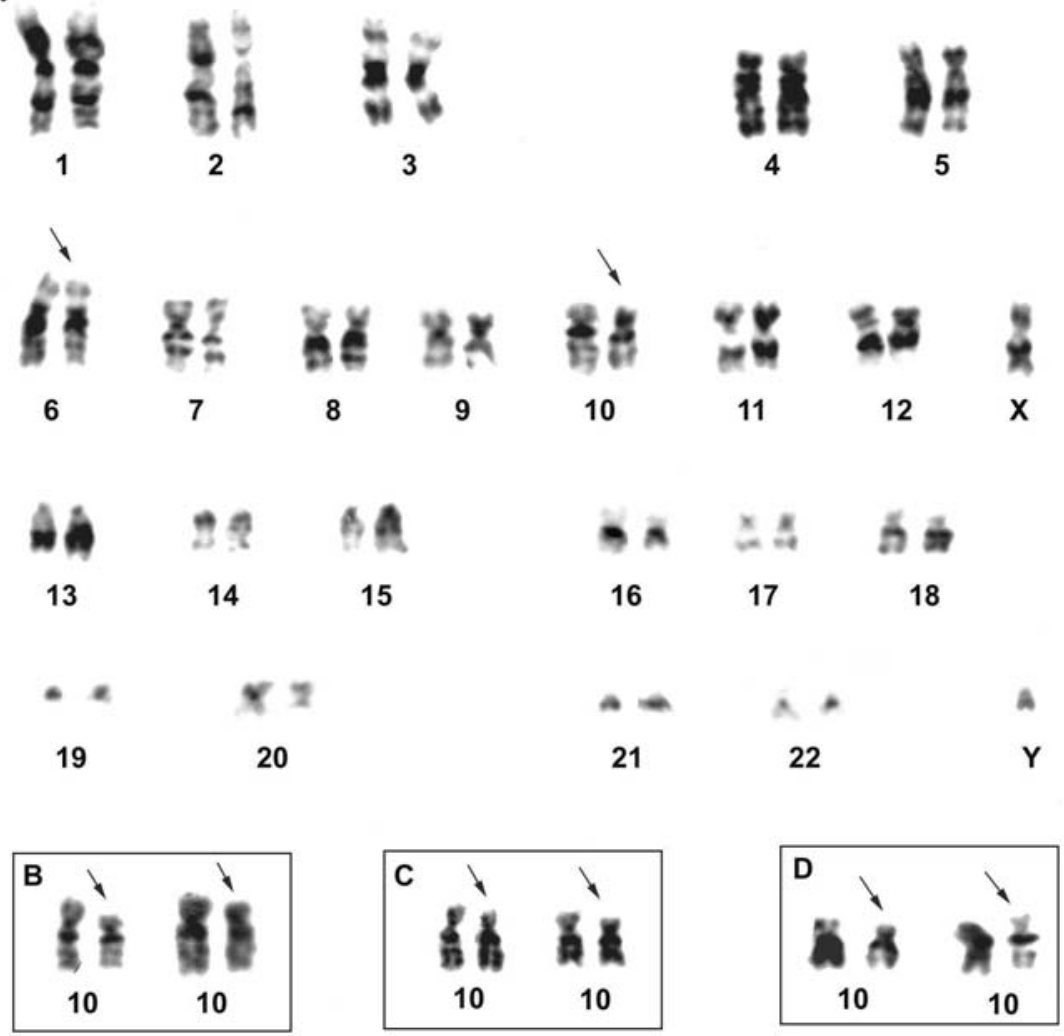

Figure 3 - (A) Metaphase of case 4 with the karyotypic formula 46,XY,del(6)(q25),del(10)(p13). (B), (C) and (D) Partial karyotypes showing $\operatorname{del}(10)(\mathrm{p} 13)$ in cases 2,3 and 4 respectively.

mesenchymal tumors are often overgrown by reactive fibroblasts.

The structural alterations were deletions $\operatorname{del}(6)(\mathrm{q} 25)$, $\operatorname{del}(7)(\mathrm{q} 33), \operatorname{del}(10)(\mathrm{p} 13)$ and del (18)(p11.2). The chromosomes and the breakpoints involved affect gene-rich areas which are important for the regulation of cell proliferation. $\operatorname{del}(6)(q 25)$ is a chromosome alteration described in benign and malignant tumors (Mitelman 1998) such as chondromixoid fibromas (Safar et al. 2000). Constitutional deletions of the same region were also described in cases of congenital malformations, including craniofacial and limb anomalies (Sukumar et al. 1999). Mapped to this region are the genes PLAGL-1 (pleomorphic adenoma gene like-1) (Abdollahi et al. 1997) and ESR1 (estrogen receptor 1) (Walter et al. 1985, Bord et al., 2001). Estrogen plays an essential role in the development and maintenance of the skeleton mediated via interactions with the estrogen receptors. ESR 1 mutations, with consequent estrogen resistance, can lead to defect in bone maturation and mineralization (Bord et al., 2001). In view of the frequency and heterogeneity of this deletion in different tumors (Mitelman 1998), the regions flanking $6 \mathrm{q} 25$ may contain one or more genes that may possibly contribute to the different stages of cell proliferation.

Deletions affecting the chromosome region $7 \mathrm{q} 33$ have been detected in some tumors and mainly in myeloid disorders (Tosi et al. 1999; Koike et al. 1999). The gene PTN (pleiotrophin) was mapped in 7q33 (Li et al. 1992). The dominant-negative action of mutant cells on breast cancer cells has been recently demonstrated recently (Zhang et al. 1999). The gene NEGF1 (neurite growthpromoting factor 1, heparin-binding cytokine family, same as $P T N$ ), mapped in this region, produces a mitogenic heparin-binding protein that is involved in the transcription and differentiation of embryonic carcinoma cells of rats (Ly et al. 1990).

The del(18)(p11.2) and monosomy of chromosome 18 , were the most frequent alteration observed in the GRCC here studied. Cytogenetic analysis of giant cell tumors has revealed that $18 \mathrm{p} 11$ is one of the regions involved in structural rearrangements or in telomeric associations (Bridge et al. 1990; Bridge et al. 1992; Schwartz et al. 1993) and in some tumor types such as adenocarcinomas, ependymomas, acute myeloid leukemia and osteosarcomas (Mitelman 1998). Important genes such as ZFP161, which codes for a zinc-finger protein and seems to be a transcriptional repressor of $c-M Y C$, have been mapped to region 18p11.21. The product of this gene has growth suppressor activity in mouse cell lines (Sobeck-Klocke et al. 1997).

The three GCT cases analyzed here consistently presented del(10)(p13) as a clonal alteration, which has been reported in some tumors such as monoblastic leukemia 
(Seo et al. 1986) and oncocytoid renal cell carcinoma (Medeiros et al.1999), but has not been previously detected in this group of tumors. In this region There are genes in this region that may be involved in human neoplasias such as RSU1 (Ras suppressor protein 1 or suppressor of transformation by activated $R A S$, ubiquitous), a regulatory gene producing a protein that suppresses genes of the RAS family (Tsuda and Cutler, 1993); STAM (signal-transducing adaptor molecule), whose protein is involved in signal translation, with a cytokine-dependent suppressive effect on cell growth (Asao et al. 1997); and VIM (vimetin, intermediate filament), whose protein participates in the regulation of mesenchymal cell growth, actively present in mammary cells. Its greatest expression occurs in aggressive and metastatic neoplasias (Hendrix et al. 1997). These genes may be targets in a subgroup of GCT.

These cytogenetic findings demonstrate that clonal and recurrent abnormalities occur in bone GCT. Although there is difficulty in the differential diagnosis, the cytogenetic pictures of GCRG and GCT are different. GCRG shows a typical non-neoplastic proliferative process. Both the changes detected in the single case reported in the literature and those described here differ from those occurring in GCT. In view of the limited number of bone GCRG described thus far and of the consistent finding of $\operatorname{del}(10)(\mathrm{p} 13)$ in the bone GCT described here, additional studies are needed to evaluate the significance and the greater specificity of these alterations. Identification of these deletions may be used as a foundation for molecular approaches to establishing the affected genes and to recognizing the associate consequences of these gene alterations in the development of bone giant cell lesions.

\section{Acknowledgments}

The authors are grateful to Vanderci Massaro de Oliveira, Márcio Rogério Penha, and Rosangela Orlandin Lopez for technical assistance. Thanks are also due to Dr. Suzanne Hensing. Research supported by FAPESP, CNPq, FAEPA, and CAPES.

\section{References}

Abdollahi A, Roberts D, Godwin AK, Schultz DC, Sonoda G, Testa JR and Hamilton TC (1997) Identification of a zincfinger gene at $6 \mathrm{q} 25$ : a chromosomal region implicated in development of many solid tumours. Oncogene 14(16):1973-1979.

Asao H, Sasaki Y, Arita T, Tanaka N, Endo K, Kasai H, Takeshita T, Endo Y, Fujita T and Sugamura K (1997) Hrs is a associated with STAM, a signal-transducing adaptor molecule: its supressive effect on cytokine-induced cell growth. J Biol Chem 272:32785-32791.

Bale SJ, Chakravarti A and Greene MH (1986) Cutaneous malignant melanoma and familial dyplastic nevi: evidence for autossomal dominance and pleitropy. Am J Hum Genet 38:188-196.
Baruffi MR, Volpon JB, Neto JB and Casartelli C (2001) Osteoid osteomas with chromosomes alterations involving 22q. Cancer Genet Cytogenet 142(2):127-131.

Bord S, Horner A, Beavan S, Compston J (2001) Estrogen receptors alpha and beta are differentially expressed in developing human bone.J Clin Endocrinol Metab 86(5):2309-14.

Bridge JA (1993) Cytogenetic and molecular cytogenetic techniques in orthopaedic surgery. J Bone Joint Surg 75:606-614.

Bridge JA, Neff JR, Bhatia PS, Sanger WG and Murphey MD (1990) Cytogenetic findings and biologic behavior of giant cell tumors of bone. Cancer 65:2697-2703.

Bridge JA, Neff JR and Mouron BJ (1992) Giant cell tumor of bone. Chromosomal analysis of 48 specimens and review of the literature. Cancer Genet Cytogenet 58:2-13.

Buresh CJ, Seemayer TA, Nelson M and Bridge JA (1999) $\mathrm{t}(\mathrm{X} ; 4)(\mathrm{q} 22 ; \mathrm{q} 31.3)$ in giant cell reparative granuloma. Cancer Genet Cytogenet 115:80-81.

Dal Cin P, Sciot R, Samson I, De Smet L, De Wever I, Van Damme B and Van den Berghe H (1994) Cytogenetic characterization of tenosynovial giant cell tumors (nodular tenosynovitis). Cancer Res 54:3986-3987.

Dorfman HD and Czerniak B (1998) Giant-cell lesions. In: Dorfman, HD and Czerniak, B (eds) Bone Tumors. $1^{\text {st }}$ ed. Mosby, Inc., St Louis, pp 559-606.

Giza E, Stern PJ, Cualing H and Cincinnati OH (1997) Agressive Giant Cell Reparative Granuloma of the Metacarpal: A Case Report. J Hand Surg 22(A):732-736.

Hendrix MJC, Seflor EA, Seflor REB and Trevor KT (1997) Experimental co-expression of vimetin and keratin intermediate filaments in human breast cancer cells results in phenotypic interconversion and increased invasive behavior. Am J Pathol 150(2):483-495.

Huvos AG (1991) Giant-cell Tumor of Bone. In: Huvos, AG (ed). Bone tumors: diagnosis, treatment, and prognosis. $2^{\text {nd }}$ ed, W.B. Saunders Company, New York, pp 429-467.

ISCN (1995) An International System for Human Cytogenetics Nomenclature. F Mitelman, ed. S Karger, Basel.

Koike M, Tasaka T, Spira S, Tsuruoka N and Koeffer HP (1999) Allelotyping of acute myelogenous leukemia: loss of heterozygosity at 7q31.1 (D7S846) and q33-34 (D7S498, D7S505). Leuk Res 23(3):307-310.

Li YS, Hoffman RM, Le Beau M, Espinosa RIII, Jenkins NA, Gilbert DJ, Copeland NG and Deul TF (1992) Characterization of the human pleiotrophin gene: promoter region and chromosomal localization. J Biol Chem 267:26011-26016.

Ly Y-S, Milner PG, Clauhan AK, Watson MA, Hoffman RM, Kodner CM, Milbrandt J and Deuel TF (1990) Cloning and expression of a developmentally regulated protein that induces mitogenic and neurite outgrowth activity. Science 250:1690-1694.

Medeiros LJ, Palmedo G, Krigman HR, Kovacs G and Beckwith JB (1999) Oncocytoid renal cell carcinoma after neuroblastoma: a report of four cases of a distintic clinicopathologic entity. Am J Surg Pathol 23(7):772-780.

Mitelman F (1998) Catalog of Chromosome Aberrations in Cancer '98. Willey-Liss. B. Johansson, F. Mertens Eds. (software).

Noguera R, Llobart-Bosh A, Lopez-Gines C, Carda C, Fernandez CI (1989) Giant-cell tumor of bone stage II, displaying 
translocation $\mathrm{t}(12 ; 19)(\mathrm{q} 13 ; \mathrm{q} 13)$. Virchows Archiv A Pathol Anat 415:377-382.

Panoutsakapoulos G, Pandis N, Kyriazoglou I, Gustafson P, Mertens F and Mandahl N (1999) Recurrent t(16;17)(q22;p13) in aneurysmal bone cysts. Genes Chromosom Cancer 26(3):265-266.

Safar A, Nelson M, Neff JR, Maale GE, Bayani J, Squire J and Bridge JA (2000) Recurrent anomalies of $6 \mathrm{q} 25$ in chondromyxoid fibroma. Hum Pathol 31(3):306-311.

Schajowicz F (2000) Lesões pseudotumorais. In: Schajowicz, F (ed) Neoplasias ósseas and lesões pseudotumorais: Patologia, Radiologia and Tratamento. $2^{\text {nd }}$ ed. Revinte R Ltda., Rio Janeiro, pp 505-612.

Scheres VMJC (1972) Identification of two Robertsonian translocations with a Giemsa-banding technique. Hum Genet 15:253-256.

Schwartz HS, Butler MG, Jerkins RB, Miller A and Moses HL (1991) Telomeric associations and consistent growth factor overexpression detected in giant cell tumor of bone. Cancer Genet Cytogenet 56:263-276.

Schwartz HS, Dahir GA and Butler MG (1993) Telomere Reduction in Giant Cell Tumor of Bone and with Aging. Cancer Genet Cytogenet 71:132-138.

Seo IS, McGuire WA, Heerena NA, Mirkin LD and Weetman RM (1986) Congenital monoblastic leukemia cutis. A case re- port with chromosomal abnormality:del(10p). Am J Pediatric Hematol Oncol 8(2):158-162.

Sobek-Klocke I, Disque-Kochem C., Ronsiek M, Klocke R, Jockusch H, Breuning A, Ponstingl H, Rojas K, Overhauser J and Eichenlaub-Ritter U (1997) The human gene ZFP161 on 18p11.21-pter encodes a purative c-myc repressor and is homologous to murine Zfp161 (Chr 17) and Zfp161-rs1. Genomics 43(2):156-164.

Sukumar S, Wang S, Hoang K, Vanchiere CM, England K, Fick R, Pagon B and Reddy KS (1999) Subtle overlapping deletions in the terminal region of chromosome 6q24.2-q26: three cases studied using FISH. Am J Med Genet 87(1):17-22.

Tosi S, Scherer SW, Giudici G, Czepulkowski B, Biondi A and Kearney L (1999) Delineation of multiple deleted regions in $7 \mathrm{q}$ in myeloid disorders. Genes Chromosom Cancer 25(4):384-392.

Tsuda T and Cutler ML (1993) Human RSU1 is a highly homologous to mouse Rsu-1 and localizes to human chromosome 10. Genomics 18:461-462.

Walter, P, Green, S, Greene, G, Krust,A, Bornert, J-M, Jeltsch J-M, Staub, A, Jensen E, Scrace G, Waterfield M and Chambon P (1985) Cloning of the human estrogen receptor cDNA. Proc Natl Acad Sci 82:7889-7893.

Zhang N, Yeh HJ, Zhong R, Li YS and Deuel TF (1999) A dominant-negative pleiotrophin mutant introduced by homologus recombination leads to germ-cell apoptosis in male mice. Proc Natl Acad Sci 96:6734-6738. 